\title{
Erythema nodosum in a child with Salmonella Enteritidis infection
}

\section{Rumień guzowaty u dziecka w przebiegu zakażenia Salmonella Enteritidis}

\author{
'Children's Department of Medical Centre of Pabianice, Pabianice, Poland \\ ${ }^{2}$ Department of Nutrition and Epidemiology, Medical University of Lodz, Kódź, Poland \\ Correspondence: Aleksandra Kamińska-Sobczak, Children's Department, Medical Centre of Pabianice, Jana Pawła II 68, 95-200 Pabianice, Poland, \\ tel.: +48 42225 3636, e-mail: aleksandra.kaminska@stud.umed.lodz.pl
}

Abstract The paper discusses a case of erythema nodosum in an almost 2-year-old boy diagnosed for fever and skin lesions on the extensor parts of the lower legs. Extended medical history and diagnosis allowed to identify Salmonella Enteritidis as the culprit of symptoms. This entity is rarely found in the paediatric population, especially in children $<2$ years of age. It clinically manifests with small, painful, red to purple subcutaneous nodules, mostly developing in the lower extremities. Only few cases of correlation between erythema nodosum and this serotype of Salmonella have been described in the available literature. Reminding general practitioners and paediatricians of the basic information about the possible course of the disease will allow for earlier differential diagnosis and more rapid and appropriate treatment.

Keywords: erythema nodosum, salmonellosis, panniculitis, diarrhoea

Streszczenie W pracy omówiony został przypadek rumienia guzowatego (erythema nodosum) u niespełna 2-letniego chłopca diagnozowanego z powodu gorączki oraz zmian skórnych na wyprostnych częściach podudzi. W toku pogłębionego wywiadu oraz rozszerzonej diagnostyki ustalono, że przyczyną objawów było zakażenie Salmonella Enteritidis. Chorobę tę rzadko obserwuje się w populacji dziecięcej, szczególnie przed 2. rokiem życia. Klinicznie objawia się ona występowaniem małych, bolesnych, czerwono-fioletowych guzów podskórnych, zlokalizowanych głównie na kończynach dolnych. W dostępnym piśmiennictwie opisano zaledwie kilka przypadków korelacji rumienia guzowatego ze wskazanym serotypem bakterii Salmonella. Przypomnienie lekarzom podstawowej opieki zdrowotnej oraz pediatrom podstawowych informacji na temat możliwego przebiegu schorzenia umożliwi wcześniejsze rozpoczęcie diagnostyki różnicowej oraz szybsze wdrożenie prawidłowego leczenia.

Słowa kluczowe: rumień guzowaty, salmonelloza, zapalenie tkanki podskórnej, biegunka 


\section{INTRODUCTION}

$\mathrm{E}$ rythema nodosum (EN) is a type of hypersensitivity reaction that may be triggered by multiple, usually infectious, factors. Erythema nodosum was first described by Robert Willan in 1798 . The worldwide prevalence of $\mathrm{EN}$ is estimated at $1-5 / 100,000$ persons. It usually affects individuals aged 18 to 34 years, and is more common among women $(3-5: 1)^{(1)}$. EN was observed to be seasonal, with a higher number of cases in the period from spring to autumn, which may be related to the increased prevalence of streptococcal infections during this time ${ }^{(2)}$. Erythema nodosum is very rare among children, but at the same time, it is the most common form of panniculitis in this group of patients. It affects boys and girls equally ${ }^{(1)}$.

The pathogenesis of EN is not fully understood. Erythema nodosum is believed to arise from Coombs type IV hypersensitivity reactions, as a cellular response to various antigens. It is known that skin lesions are caused by the deposition of immune complexes in the vessels and septa of fat lobules, and histopathological examination shows an inflammatory infiltrate consisting of neutrophils, lymphocytes and eosinophils. Furthermore, ED is characterised by the presence of so-called Miescher's radial granulomas - aggregates of small histiocytes arranged around a central cleft ${ }^{(1,2)}$.

The typical picture of erythema nodosum is an acute eruption of painful, warm, poorly demarcated, red-purple subcutaneous nodules. They are usually located symmetrically on the extensor surfaces of the lower legs, much less often on the thighs, buttocks, torso, arms, forearms, neck or face. The lesions are $1-5 \mathrm{~cm}$ in diameter. The nodules usually persist for 2-6 weeks, they become flat over time and change colour to brown-green, and then yellow ${ }^{(1,2)}$. It can be concluded based on the literature that the duration of skin lesions is related to the aetiology of the disease; it is on average 12 days in patients with acute infectious diseases and 21 days in patients with chronic diseases ${ }^{(3)}$. The lesions resolve without scarring or necrosis. The appearance of nodules may be accompanied by general symptoms such as fever, weakness, and joint, head or abdominal pain. Furthermore, depending on the aetiological factor, symptoms of upper respiratory tract infection, conjunctivitis or diarrhoea may also occur $^{(1,2)}$. The differential diagnosis of skin lesions should include, among other things, Henoch-Schönlein purpura, battered child syndrome, urticaria, erysipelas, insect bites, rheumatoid nodules, thrombophlebitis, polyarteritis nodosa, skin involvement by proliferative diseases, and familial Mediterranean fever ${ }^{(1,4)}$.

Although infections are the primary cause of EN, other ethological factors, such as inflammatory bowel disease or autoimmune diseases, such as coeliac disease, systemic lupus, rheumatoid arthritis, Sjögren's syndrome, Behçet's disease, polymyositis and dermatomyositis or vascular

\begin{tabular}{|c|c|}
\hline Infectious factors & $\begin{array}{l}\text { - Streptococcus spp. } \\
\text { - Yersinia enterocolitica } \\
\text { - Yersinia pseudotuberculosis } \\
\text { - Mycobacterium tuberculosis } \\
\text { - Salmonella spp. } \\
\text { - Campylobacter jejuni } \\
\text { - Chlamydia trachomatis } \\
\text { - Mycoplasma pneumoniae } \\
\text { - Helicobacter pylori } \\
\text { - Giardia lamblia } \\
\text { - Bartonella henselae } \\
\text { - Toxoplasma gondii } \\
\text { - EBV } \\
\text { - CMV } \\
\text { - HBV } \\
\text { - HCV } \\
\text { - Parvovirus B19 } \\
\text { - HIV }\end{array}$ \\
\hline Inflammatory bowel diseases & $\begin{array}{l}\text { - Crohn's disease } \\
\text { - Ulcerative colitis }\end{array}$ \\
\hline Autoimmune diseases & $\begin{array}{l}\text { - Coeliac disease } \\
\text { - Systemic lupus } \\
\text { - Sjögren's syndrome } \\
\text { - Behçet's disease } \\
\text { - Polymyositis } \\
\text { - Dermatomyositis } \\
\text { - Vasculitis }\end{array}$ \\
\hline Cancer & $\begin{array}{l}\text { - Leukaemias } \\
\text { - Lymphomas }\end{array}$ \\
\hline Pharmacotherapy & $\begin{array}{l}\text { - NSAIDs } \\
\text { - Paracetamol } \\
\text { - Antibiotics (e.g. amoxicillin) }\end{array}$ \\
\hline $\begin{array}{l}\text { Vaccinations against } \\
\text { infectious diseases }\end{array}$ & $\begin{array}{l}\text { - Tuberculosis } \\
\text { - Diphtheria, tetanus, pertussis } \\
\text { - Hepatitis B } \\
\text { - Rabies } \\
\text { - Human papillomavirus } \\
\end{array}$ \\
\hline \multicolumn{2}{|c|}{$\begin{array}{l}\text { CMV - cytomegalovirus; EBV - Epstein-Barr virus; HBV - hepatitis B virus; } \\
\text { HCV - hepatitis C virus; HIV - human immunodeficiency virus; } \\
\text { NSAIDs - non-steroidal anti-inflammatory drugs. }\end{array}$} \\
\hline
\end{tabular}

Tab. 1. Differential diagnosis of the aetiology of EN in children

inflammations, should not be forgotten ${ }^{(2,4-6)}$ (Tab. 1). Erythema nodosum may be the first sign of a systemic disease; therefore, if symptoms persist for a longer period of time, thorough diagnosis is recommended ${ }^{(3)}$.

Erythema nodosum can also occur during pharmacotherapy. Antibiotics (amoxicillin, ciprofloxacin, levofloxacin), non-steroidal anti-inflammatory drugs and paracetamol are of the greatest importance in the paediatric population ${ }^{(2)}$.

Erythema nodosum has been also reported to coincide with vaccinations. There are reports on ED associated with vaccinations against tuberculosis, diphtheria, tetanus, pertussis, hepatitis $B$, rabies and human papillomavirus ${ }^{(1)}$. Despite the increasingly accurate diagnostic methods, the aetiology of approximately $50 \%$ of EN cases remains unknown ${ }^{(1)}$. The basic diagnostic workup needed in a patient with EN includes complete blood cell count with white blood cells (WBC) differential, C-reactive protein (CRP), erythrocyte sedimentation rate (ESR), throat swab for group A beta-haemolytic streptococcus, anti-streptolysin O (ASO) titre test 


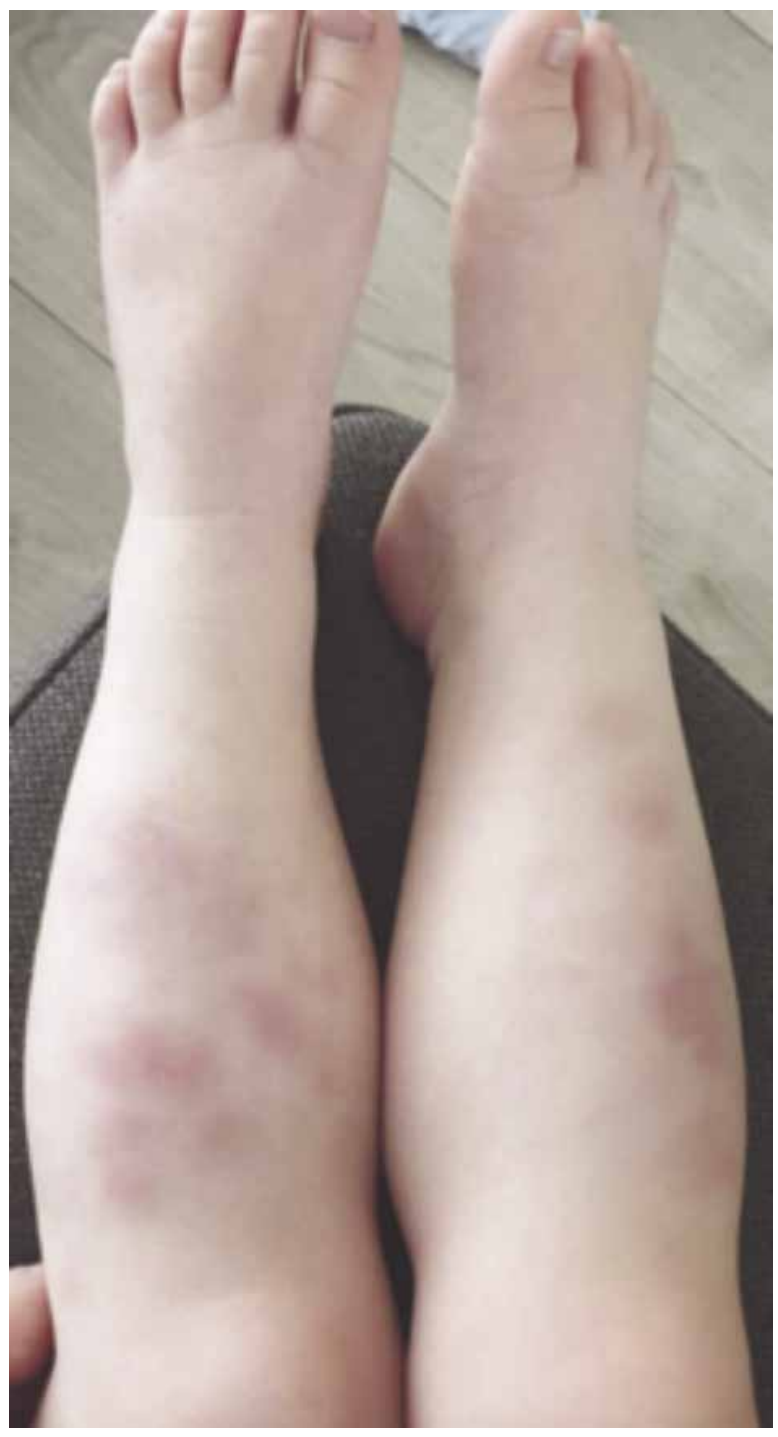

Fig. 1. Nodular lesions on the shins (day 5 after disease onset)

and chest $\mathrm{X}$-ray. Other diagnostic tests are selected individually, based on medical history, physical examination and suspected aetiology ${ }^{(1,7)}$. Biopsy is usually not needed to establish the diagnosis; the histopathological picture is typical of panniculitis ${ }^{(4,7)}$.

Causal treatment depends on the underlying disease. Symptomatic treatment includes rest ${ }^{(2,8)}$, non-steroidal anti-inflammatory drugs. Mild corticosteroids and heparinoid ointments are used topically ${ }^{(2)}$. Systemic corticosteroids are not recommended due to the possible infectious aetiology of the disease, but may be necessary if the lesions persist for more than 6 weeks ${ }^{(2)}$.

\section{CASE REPORT}

A 22-month-old boy was admitted to the hospital with fever and skin lesions persisting for 4 days. It was found that the child had looser stools for about 2 weeks, and

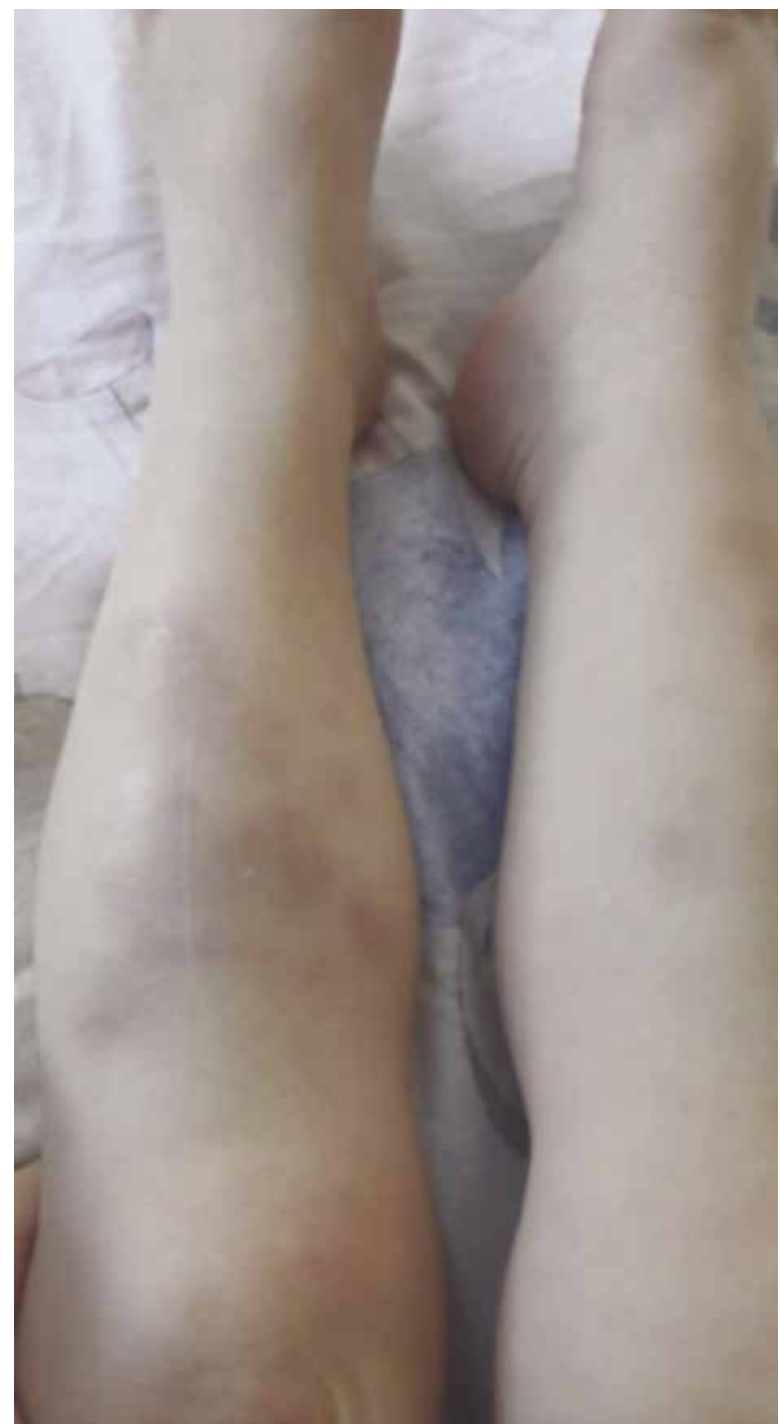

Fig. 2. Evolution of skin lesions on the shins (day 9 after disease onset)

8 hours) and painless lumps on the extensor surfaces of the lower legs on day 10 of gastroenteritis. During this time, the patient was consulted twice by a primary care physician, and outpatient laboratory tests (morphology, CRP) showed no significant abnormalities. An antibiotic was prescribed (he received 2 doses of cefuroxime $30 \mathrm{mg} / \mathrm{kg}$ body weight/day), and a topical dimetindene and hydrocortisone for skin lesions. Extended medical history showed that a week before the symptoms appeared, the boy's grandparents, who were at that time taking care of him, showed symptoms of infection with fever and muscle pains, and the grandmother had an episode of diarrhoea lasting for several days.

The boy was born at term by caesarean section, with a body weight of 3,290 $\mathrm{g}$ and an Apgar score of 10 . He was vaccinated in accordance with the Immunization Schedule $(1 \times$ BCG , $3 \times$ Hexacima, $3 \times$ Synflorix, $2 \times$ Rotarix $)$; the last vaccination was 5 months earlier (Hexacima). The child had no history of serious diseases. 
Physical examination on admission showed convex nodular bluish-red lesions, non-tender on palpation. Furthermore, there were signs of pharyngitis and mild dehydration. Laboratory tests showed increased inflammatory markers: CRP $(27.6 \mathrm{mg} / \mathrm{L} ; \mathrm{N}:<5 \mathrm{mg} / \mathrm{L})$, ESR $(56 \mathrm{~mm} / \mathrm{h})$ and a slightly prolonged activated partial thromboplastin time (APTT) (39.5 s). Due to the epidemiological situation, tests for SARS-CoV-2 were performed: total IgG/IgM antibodies were absent, and the nasopharyngeal swab was negative (real time polymerase chain reaction, RT-PCR). Differential diagnosis of EN excluded infections with atypical bacteria (Mycoplasma pneumoniae, Chlamydia pneumoniae), Bartonella henselae, parasitic infestations (gastrointestinal parasites, Toxoplasma gondii) and viral infections [Epstein-Barr virus (EBV), cytomegalovirus (CMV)]. Stool tests for rota-, adeno-, and noroviruses and Campylobacter sp. were also negative. Calprotectin (normal) was measured as part of inflammatory bowel diseases screening. Chest radiography showed a shadow of the mediastinum of an untypical configuration (outpatient cardiac echocardiography showed no abnormalities after hospital stay). Initially, parenteral cefuroxime was used $(30 \mathrm{mg} / \mathrm{kg}$ body weight/day), followed by ceftriaxone $(50 \mathrm{mg} / \mathrm{kg}$ body weight/day) from day 5 , which was continued after receiving information about a positive stool culture (Salmonella Enteritidis). The remaining cultures (blood, urine, throat swab) were negative.

During hospitalisation, the patient initially developed fever, had a few loose stools, vomited, and required parenteral hydration. At that time, new skin lesions appeared, and the existing ones expanded and changed their morphology (from pink spots to initially red and then blue lumps) (Figs. 1, 2). After changing the antibiotic, the boy's condition began to improve quite quickly. Fever and diarrhoea resolved, appetite improved, and the nodular lesions gradually reduced and resolved completely after 16 days. Considering the clinical picture and family history, Salmonella Enteritidis infection was considered the cause of disease symptoms, including EN.

\section{DISCUSSION}

Literature analysis shows that Streptococcus pyogenes infections are currently the main cause $(22-48 \%)$ of EN in developed countries, and that tuberculosis remains an important factor in endemic regions such as India, Thailand, Turkey, and South Africa ${ }^{(1)}$. Yersinia enterocolitica and Yersinia pseudotuberculosis also contribute to $\mathrm{EN}$ in the paediatric population. Other reported infectious factors include, among other things, Salmonella spp., Campylobacter jejuni, Chlamydia trachomatis, Mycoplasma pneumoniae, Coxiella burnetii, Bartonella henselae, Helicobacter pylori, Giardia lamblia, Toxoplasma gondii, EBV, CMV, hepatitis B virus (HBV) and hepatitis C virus (HCV), parvovirus B19, human immunodeficiency virus (HIV), and parapoxvirus ${ }^{(1)}$. In a study among Swiss children, streptococcal infections were the most common aetiology of $\mathrm{EN}^{(5)}$. Similar observations were made by Turkish ${ }^{(3,7)}$ and Greek ${ }^{(9)}$ researchers. A study among children from Israel reported streptococcal infections followed by EBV infections ${ }^{(4)}$.

The first case of EN coexisting with salmonellosis was published by Grossman and Katz in $1984^{(10)}$.

Only few case reports of ED in patients diagnosed with Salmonella infection can be found in English-language literature $^{(9-13)}$. S. Typhimurium and $S$. Typhi ${ }^{(13)}$ are the most common causes of EN, whereas $S$. Enteritidis is less commonly reported ${ }^{(10)}$. Greek scientists concluded that the incidence of salmonellosis associated with EN depends both on the prevalence of salmonellosis and on the genetic factors in a given population ${ }^{(9)}$. The diagnosis is based on clinical symptoms and a positive stool culture. Nodular lesions on the shins usually appeared within 3 days to 2 weeks from the onset of gastrointestinal symptoms and persisted for up to 2-7 weeks. Overlapping arthritis has been reported in some cases. In most cases, the symptoms resolved spontaneously with no need for antibiotic treatment ${ }^{(13)}$. However, in severe cases with increased gastrointestinal symptoms, prolonged fever and accompanying extra-gastrointestinal symptoms, antibiotic therapy is justified $^{(13,14)}$.

\section{CONCLUSIONS}

A detailed medical history is of fundamental importance in determining the cause of EN and making an accurate diagnosis. It is also important to consider various aetiological factors of this disease, which is rare in the paediatric population.

\section{Conflict of interest}

The authors do not report any financial or personal connections with other persons or organisations, which might negatively affect the contents of this publication and/or claim authorship rights to this publication.

\section{References}

1. Leung AKC, Leong KF, Lam JM: Erythema nodosum. World J Pediatr 2018; 14: 548-554.

2. Potempa-Jeziorowska M, Sedlaczek K, Jonczyk P et al.: Rumień guzowaty - jeden objaw, wiele przyczyn? Pediatr Med Rodz 2018; 14: 381-385.

3. Cengiz AB, Kara A, Kanra G et al.: Erythema nodosum in childhood: evaluation of ten patients. Turk J Pediatr 2006; 48: 38-42.

4. Garty BZ, Poznanski O: Erythema nodosum in Israeli children. Isr Med Assoc J 2000; 2: 145-146.

5. Hassink RI, Pasquinelli-Egli CE, Jacomella $\mathrm{V}$ et al.: Conditions currently associated with erythema nodosum in Swiss children. Eur J Pediatr 1997; 156: 851-853.

6. Litwin L, Machura E: The etiology and clinical manifestation of erythema nodosum in hospitalized children - analysis of 12 cases. Preliminary report. Dev Period Med 2014; 18: 506-512. 
7. Aydın-Teke T, Tanır G, Bayhan GI et al.: Erythema nodosum in children: evaluation of 39 patients. Turk J Pediatr 2014; 56: 144-149.

8. Kakourou T, Drosatou P, Psychou F et al.: Erythema nodosum in children: a prospective study. J Am Acad Dermatol 2001; 44: 17-21.

9. Mantadakis E, Arvanitidou V, Tsalkidis A et al.: Erythema nodosum associated with Salmonella enteritidis. Hippokratia 2010; 14: 51-53.

10. Hassan A, Alsaihati A, Al Shammari M et al.: Erythema nodosum: a manifestation of Salmonella infection. Case Rep Gastroenterol 2019; 13: 456-461.

11. Al Benwan $\mathrm{K}, \mathrm{Al}$ Mulla $\mathrm{A}$, Izumiya $\mathrm{H}$ et al.: Erythema nodosum and bilateral breast abscesses due to Salmonella enterica serotype Poona. J Clin Microbiol 2010; 48: 3786-3787.
12. Castilla Cortázar A, Pastor Rodríguez A, Montejo Baranda M et al.: Salmonella gastroenteritis and erythema nodosum. Can Med Assoc J 1985; 133: 120.

13. Haider S, Brar I, Mateo NB et al.: Erythema nodosum and Salmonella enteritidis: a rare clinical association. Infect Dis Clin Pract 2000; 9: 223-224.

14. Wen SC, Best E, Nourse C: Non-typhoidal Salmonella infections in children: review of literature and recommendations for management. J Paediatr Child Health 2017; 53: 936-941. 